\title{
SOSIALISASI SISTEM MANAJEMEN RUMAH SAKIT \\ DALAM MENANGANI KESELAMATAN DAN \\ KESEHATAN PASIEN
}

\author{
Muhammad Firdaus ${ }^{1}$, Marian Tonis ${ }^{2}$, Bobi Handoko ${ }^{3}$,Abdul Zaky ${ }^{3}$ \\ STIKes Awal Bros Pekanbaru \\ Program Studi S1 Administrasi Rumah Sakit \\ ${ }^{1}$ dauz.messi@gmail.com
}

\begin{abstract}
All medical actions against patients must have their own risks. Certainly not a single health worker or doctor would want his patient to experience this unwanted risk. Therefore, patient safety must be prioritized in every medical treatment. Every medical staff must understand it, so they can apply it properly. Patient safety is of key importance to any health facility. PKM activities were held on September 4, 2020, Tangkerang Selatan Village, Bukit Raya District, Pekanbaru City. This community service aims to provide knowledge to the public about management information systems in hospitals, provide knowledge about existing services in hospitals and how to get excellent service. The results obtained from community service are that the community understands the method and flow of treatment and services at the hospital. The community also understands the services available at the hospital and how to get excellent service. For continuation, it is recommended to carry out further research on this guidance approach on a broader subject, easier material and more relevant methods so that generalizations can be drawn.
\end{abstract}

Keywords: Hospital Management System, patient safety

\begin{abstract}
ABSTRAK
Seluruh tindakan medis terhadap pasien pasti memiliki risiko tersendiri. Pastinya tidak ada satu petugas kesehatan atau dokter pun yang menginginkan pasiennya mengalami risiko tidak diinginkan tersebut. Oleh sebab itu, keselamatan pasien harus diutamakan dalam setiap penanganan medis. Setiap tenaga medis harus memahaminya, sehingga bisa menerapkannya dengan baik. Keselamatan pasien adalah kunci penting bagi setiap fasilitas kesehatan. Kegiatan PKM dilaksanakan pada 04 September 2020 Kelurahan Tangkerang Selatan, Kecamatan Bukit Raya, kota Pekanbaru. Pengabdian masyarakat ini bertujuan untuk Memberikan pengetahuan kepada masyarakat tentang sistem informasi manajemen di rumah sakit, Memberikan pengetahuan tentang pelayanan yang ada dirumah sakit serta cara mendapatkan layanan yang prima. Hasil yang didapatkan dari pengabdian masyarakat adalah masyarakat memahami tentang cara dan alur berobat serta layanan yang ada dirumah sakit. Masyarakat juga memahami pelayanan yang ada dirumah sakit serta cara mendapatkan layanan yang prima. Untuk kelanjutan disarankan melakukan penelitian lanjutan tentang pendekatan bimbingan ini pada subjek yang lebih luas, materi yang lebih mudah dan metode yang lebih relevan sehingga dapat ditarik generalisasinya.
\end{abstract}

Keywords: Sistem Manajemen Rumah Sakit, keselamatan pasien 


\section{PENDAHULUAN}

Undang-Undang Nomor 44 Tahun 2009 tentang Rumah Sakit, Pasal 43 ayat (1) mewajibkan Rumah Sakit menerapkan standar keselamatan pasien. Yang dimaksud dengan keselamatan pasien (patien safety) adalah proses dalam suatu Rumah Sakit yang memberikan pelayanan pasien yang lebih aman. Termasuk di dalamnya asesmen risiko, identifikasi, dan manajemen risiko terhadap pasien, pelaporan dan analisis insiden, kemampuan untuk belajar dan menindaklanjuti insiden, dan menerapkan solusi untuk mengurangi serta meminimalisir timbulnya risiko.

Standar keselamatan pasien tersebut menurut Pasal 43 ayat (2) dilaksanakan melalui pelaporan insiden, menganalisa, dan menetapkan pemecahan masalah dalam rangka menurunkan angka kejadian yang tidak diharapkan.Yang dimaksud dengan insiden keselamatan pasien adalah kesalahan medis (medical error), kejadian yang tidak diharapkan (adverse event), dan nyaris terjadi (near miss). Untuk meningkatkan mutu pelayanan Rumah Sakit, Menteri Kesehatan menurut Pasal 3 ayat (1) Perat uran Menteri Kesehatan Nomor 1691/Menkes/Per/VIII/2011 tentang Keselamatan Pasien Rumah Sakit, membentuk Komite Nasional Keselamatan Pasien Rumah Sakit.

Komite Nasional tersebut merupakan organisasi nonstruktural dan independen dibawah koordinasi direktorat jenderal yang membidangi rumah sakit, serta bertanggung jawab kepada Menteri. Keanggotaan Komite ditetapkan dengan Keputusan Menteri Kesehatan atas usulan Direktur Jenderal Bina Upaya Kesehatan. Jumlahnya 11 orang yang terdiri dari unsur Kementerian Kesehatan, asosiasi perumahsakitan dan pakar perumahsakitan. Tugas Komite adalah memberikan masukan dan pertimbangan kepada Menteri Kesehatan dalam rangka penyusunan kebijakan nasional dan peraturan keselamatan pasien Rumah Sakit. Rumah Sakit dan tenaga kesehatan yang bekerja di Rumah Sakit wajib melaksanakan program dengan mengacu pada kebijakan nasional Komite Nasional Keselamatan Pasien Rumah Sakit.

Seluruh tindakan medis terhadap pasien pasti memiliki risiko tersendiri. Pastinya tidak ada satu petugas kesehatan atau dokter pun yang menginginkan pasiennya mengalami risiko tidak diinginkan tersebut. Oleh sebab itu, keselamatan pasien harus diutamakan dalam setiap penanganan medis. Setiap tenaga medis harus memahaminya, sehingga bisa menerapkannya dengan baik. Keselamatan pasien adalah kunci penting bagi setiap fasilitas kesehatan. Hal ini pula yang menjadi indikator sangat penting dalam penilaian sebuah rumah sakit. Terutama dalam kepentingan akreditasinya sebagai standar mutu atas pelayanan dan kinerjanya. Untuk menjamin hal tersebut, maka sudah ditetapkan 6 sasaran keselamatan pasien. Secara internasional ketentuan tersebut dikenal dengan istilah IPSG (International Patient Safety Goals). Dalam peraturan tersebut ada enam sasaran untuk menjamin keselamatan pasien. Ketentuan itu dirilis oleh Joint Commission International atau JCI. 
Lembaga ini memberikan dedikasinya untuk peningkatan kualitas layanan fasilitas kesehatan dan juga keselamatan bagi pasien.

Misi dari JCI adalah senantiasa meningkatkan kualitas kesehatan secara berkelanjutan untuk setiap masyarakat. Dengan cara menjalin kerjasama bersama seluruh stakeholder terkait, melakukan evaluasi terhadap organisasi pelayanan kesehatan, dan menjadi inspirasi untuk peningkatan pelayanan pria, efektif dan berkualitas tinggi. Saat ini baru tercatat beberapa saja rumah sakit di tanah air yang sudah berhasil mendapatkan akreditasi dari lembaga tersebut. Nah, IPSG yang dirilis oleh JCI sudah diaplikasikan hampir di setiap rumah sakit di seluruh dunia. Kemudian ketentuan itu pun menjadi pijakan pemerintah Indonesia melalui Kementrian Kesehatan dengan menerbitkan Permenkes-RI no. 1691/MENKES/PER/VII/2011.

Peraturan itu terkait dengan keselamatan para pasien yang dirawat di rumah sakit. Dengan dasar kuat dari JCI maka pemerintah Indonesia pun berupaya untuk melindungi pasien dengan mengutamakan keselamatan pasien (patient safety).

\section{METODE}

Kegiatan pelaksanaan PKM dilaksanakan pada hari Jumat tanggal 04 September 2020 di di Kelurahan Tangkerang Selatan, Kecamatan Bukit Raya, kota Pekanbaru. Materi yang disajikan pada pengabdian masyarakat ini adalah tentang sosialisasi Sistem Manajemen Rumah Sakit dalam menangani keselamatan dan kesehatan pasien.

Metode kegiatan pengabdian kepada masyarakat ini adalah memberikan penyuluhan dan diskusi. Adapun sasaran dalam kegiatan pengabdian masyarakat ini adalah masyarakat dan kader kesehatan di
Kelurahan Tangkerang Selatan, Kecamatan Bukit Raya, kota Pekanbaru. Adapun organisasi dari pelaksanaan pengabdian masyarakat ini sebagai berikut:

1. Narasumber : Ns. Muhammad Firdaus, S.Kep., MMR

2. Penanggung Jawab :

Marian Tonis, SKM.,MKM

Bobi Handoko,SKM.M,Kes.

Abdul Zaky.M.Si

3. Panitia Pelaksana

Ketua Pelaksana : Meidita tifany

Sekretaris : Andra Fristasya

Bendahara : Nurhayati

Adapun tujuan dan target capaian dari pelaksanaan pengabdian kepada masyarakat ini adalah :

1. Bagi Panitia Pelaksana:

a. Memberikan pengalaman kepada mahasiswa dalam membuat perencanaan kegiatan seperti menyusun proposal, mengundang masyarakat untuk ikut serta dalam kegiatan dan menyiapkan perlengkapan kegiatan pengabdian masyarakat

b. Memberikan pengalaman kepada mahasiswa dalam melaksanakan suatu kegiatan seperti memandu kegiatan, memberikan kata sambutan panitia, panitia memberikan arahan terhadap kegiatan.

c. Memberikan pengalaman kepada mahasiswa dalam membuat laporan kegiatan.

2. Bagi Peserta Pengabdian Masyarakat
a. Memberikan pengetahuan kepada masyarakat tentang sistem informasi manajemen di rumah sakit.
b. Memberikan pengetahuan tentang pelayanan yang ada dirumah sakit serta cara mendapatkan layanan yang prima.
c. Memberikan pengetahuan tentang 
cara dan alur berobat serta layanan yang ada di rumah sakit.

\section{HASIL DAN IMPLIKASI}

Kegiatan pengabdian kepada masyarakat yang dilaksanakan di Kelurahan Tangkerang Selatan, Kecamatan Bukit Raya, kota Pekanbaru, diawali dengan meninjau lokasi pengabdian masyarakat serta pendekatan kepada pihak desa serta tokoh masyarakat setempat. Ketua pelaksana mengajukan ijin penggunaan lahan pengabdian masyarakat serta rapat koordinasi dengan pihak-pihak terkait yang dilaksanakan pada tanggal 20 Agustus 2020. Rapat diawali dengan pembukaan dan pengarahan dari Kepala LPPM STIKes Awal Bros Pekanbaru. Selanjutnya, pengarahan dari ketua pelaksana mengenai mekanisme pelaksanaan kegiatan pengabdian masyarakat di Kelurahan Tangkerang Selatan, Kecamatan Bukit Raya, kota Pekanbaru, Koordinasi dengan kader kesehatan yang ada dilokasi.

Pelaksanaan kegiatan penyuluhan di Kelurahan Tangkerang Selatan, Kecamatan Bukit Raya, kota Pekanbaru berjalan dengan lancar. Kegiatan diawali dengan pemberian pre-test untuk mengukur pengetahuan awal tentang keselamatan dan kesehatan pasien. Penyuluhan dilaksanakan dengan membagikan leaflet sebagai media penyuluhan. Penyampaian materi dilakukan dengan gambar-gambar yang menarik serta diskusi sehingga peserta menjadi antusias dalam mendengarkan penjelasan yang diberikan. Pemahaman peserta setelah penyuluhan diukur dengan memberikan post-test. Soal post-test yang diberikan sama dengan soal pre-test.

Pengetahuan merupakan hasil dari tahu, dan hal ini terjadi setelah orang melakukan penginderaan terhadap suatu obyek tertentu dalam membentuk tindakan seseorang suatu objek tertentu melalui panca indera manusia yaitu indera penglihatan, pendengaran, penciuman rasa dan raba. Dengan adanya pengetahuan yang baik maka akan terbentuk tindakan seseorang dan perilaku yang didasari oleh pengetahuan yang baik akan lebih langgeng daripada perilaku yang tidak didasari oleh pengetahuan, sehingga aspek pengetahuan ini merupakan hal yang sangat berpengaruh dan penting karena pengetahuan akan membentuk keyakinan tertentu sehingga seseorang dapat berperilaku sesuai dengan keyakinannya.

Banyak faktor-faktor yang mempengaruhi pengetahuan antara lain sosial ekonomi, budaya, pendidikan dan pengalaman. Pengetahuan seseorang didukung oleh lingkungan sosialnya, jika ekonomi baik maka pendidikan seseorang juga baik sehingga memiliki pengetahuan yang baik juga (Notatmodjo, 2010). Semakin tinggi pendidikan maka akan semakin mudah menerima hal-hal baru dan mudah menyesuaikan. Selain itu informasi yang baru didapat akan disaring sesuai dengan budaya dan keyakinananya yang ada sehingga budaya sangat berpengaruh terhadap tingkat pengetahuan seseorang. Umur dan pendidikan seseorang juga akan mempengaruhi terhadap pengalaman seseorang sehingga akan lebih matang berpikir dan siap menerima informasi. Ketika seseorang telah siap dan memiliki sikap positive secara otomatis akan timbul motivasi atau keinginan berperilaku terhadap hal yang positif sehingga sangat memungkinkan ibu mau berperilaku sesuai dengan apa yang diketahuinya dan yang diyakininya.

Melalui pengabdian masyarakat ini, masyarakat di Kelurahan Tangkerang Selatan, Kecamatan Bukit Raya, kota Pekanbaru memahami terkait system manajemen dalam dalam menjaga keselamatan dan kesehatan pasien . Pada hari Jumat pukul 08.30 wib pagi dosen dan mahasiswa datang ke balai desa dan panitia mempersiapkan perlengkapan untuk melakukan sosialisasi (pengabdian kepada masyarakat). Pemateri yang sudah ditunjuk oleh panitia untuk menyampaikan materi. 
Meskipun acara sosialisasinya sedikit agak telat dilaksanakannya tetapi tidak mengurangi antusias masyarakat tentang pengabdian masyarakat ini. Panitiapun selalu mendampingi masyarakat jika ingin bertanya dan selalu mengarahkan.

\section{SIMPULAN}

1. Kegiatan pengabdian masyarakat dapat diselengarakan dengan baik dan berjalan lancar sesuai dengan jadwal dan mekanisme pelaksanaan kegiatan yang telah disusun oleh tim pengabdian masyarakat serta disepakati oleh masyarakat.

2. Penyuluhan dan sosialisasi system manajemen rumah sakit dalam menangani keselamatan dan kesehatan pasien telah dilakukan dengan hasil memuaskan.

\section{SARAN}

Rekomendasi untuk kegiatan ini sebaiknya memberikan kesempatan kepada masyarakat umum untuk mengetahui lebih jauh lagi tentang tentang sistem informasi manajemen dan pelayanan di rumah sakit. Agar memudahkan masyarakat jika ingin berobat di setiap rumah sakit. Masyarakat juga mengetahui sistem dan alur yang ada di setiap rumah sakit. Dan untuk para pihak lain disarankan melakukan penelitian lanjutan tentang pendekatan bimbingan ini dikenakan pada subjek yang lebih luas, materi yang lebih umum dan metode yang lebih relevan sehingga dapat ditarik generalisasinya.

\section{DAFTAR PUSTAKA}

Cahyono, B. 2008. Membangun Budaya Keselamatan Pasien Dalam Praktik Kedokteran. Yogyakarta: Penerbit Kanisius..

Depkes RI. 2006. Panduan Nasional Keselamatan Pasien Rumah Sakit. Jakarta: Depkes RI.

Notoatmodjo, S., 2010, Promosi Kesehatan dan Perilaku Kesehatan, Jakarta : Rineka Cipta

Depkes RI. 2008. Upaya Peningkatan Mutu Pelayanan Rumah Sakit. (konsep dasar dan prinsip). Jakarta: Depkes RI.

Dwiyanto, A. 2007. Penerapan Hospital by Laws Dalam Meningkatkan Patient Safety di Rumah Sakit. [Thesis]. Semarang: Program Pascasarjana UNIKA Soegijapranata..

Mukti, A.G. 2007. Strategi Terkini Peningkatan Mutu Pelayanan Kesehatan: Konsep dan Implementasi, Pusat Pengembangan Sistem Pembiayaan dan Manajemen Asuransi/Jaminan Kesehatan, Yogyakarta: Fakultas Kedkteran Universitas Gajah Mada

Peraturan Menteri Kesehatan 1691/MENKES/PER/VIII/2011 tentang Keselamatan Pasien Rumah Sakit 